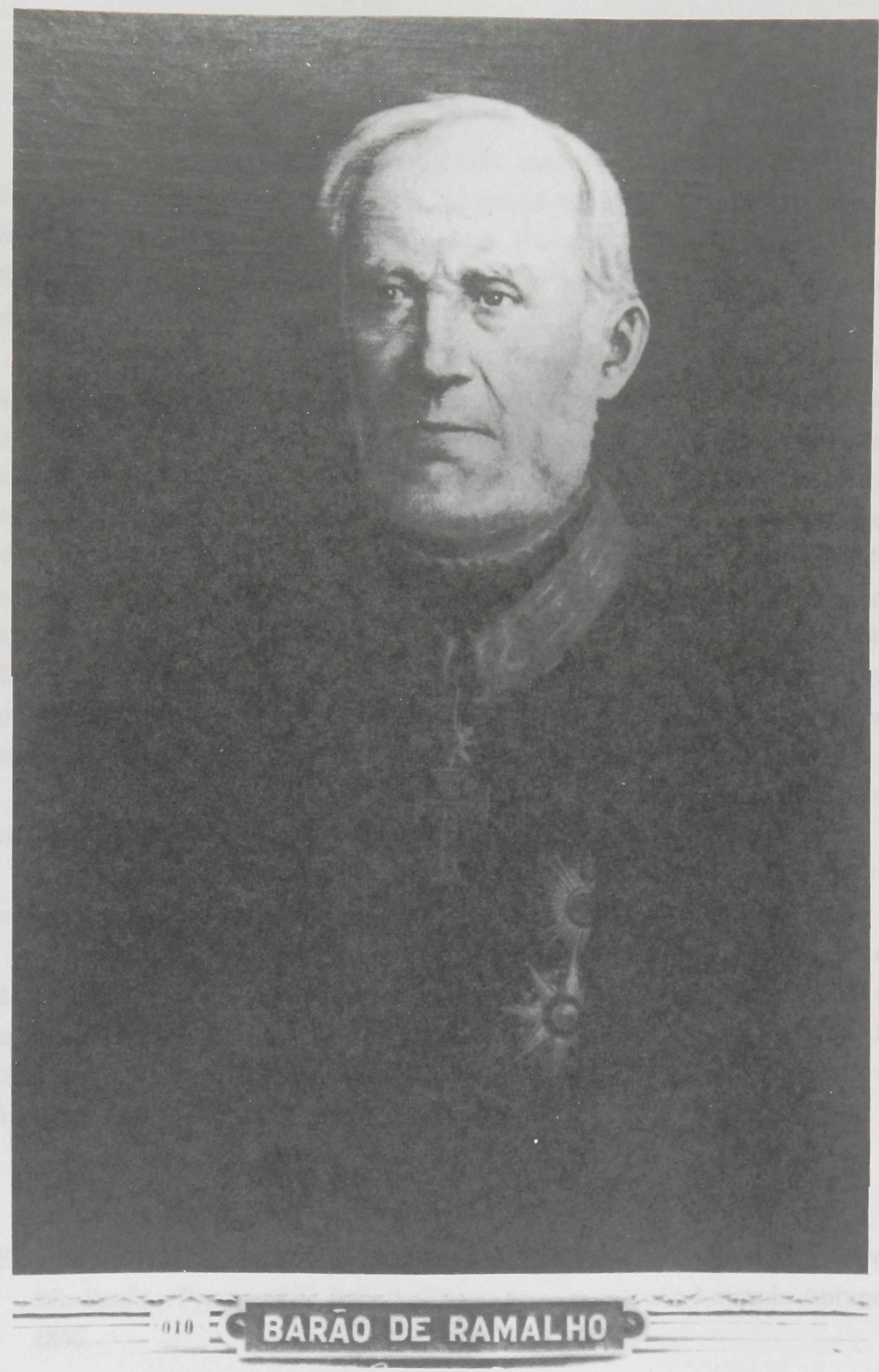





\section{Conselheiro Dr. JOAQUIM IGNACIO RAMALHO \\ (Barão de Ramalho)}

(1891-1902)

Nasceu na cidade de São Paulo, aos 6 de janeiro de 1809. Filho do licenciado em cirurgia, José Joaquim de Souza Saquette, espanhol, tornou-se filho adotivo dos irmãos Antonio Nunes Ramalho e D. Anna Felisberta Ramalho, dos quais tomou o sobrenome, e foi educado na velha escola dos rígidos costumes paulistas.

Cursava ainda o último ano do curso jurídico, em São Paulo, quando, a 3 de abril de 1834, foi nomeado lente substituto de filosofia racional e moral do Curso Anexo, cadeira de que se tornou proprietário em 22 de julho de 1836. Bacharel em direito a 25 de outubro de 1834, recebeu o grau de doutor em 1835. Foi nomeado lente substituto da Faculdade de Direito por decreto de 23 de abril de 1836, tomando posse em 28 de maio do mesmo ano. Em 1845, foi vereador e presidente da Câmara Municipal de São Paulo, de onde foi chamado à administração da província de Goiás, por carta imperial de 16 de maio de 1845 . Deputado geral pela província de Goiás em 1848, foi, membro da Assembléia provincial de São Paulo por duas legislaturas. Pelos seus serviços, o governo, por carta de $1^{\underline{9}}$ de setembro de 1846 , concedeu-lhe o oficialato da Ordem da Rosa.

Por decreto de 8 de julho de 1854 foi nomeado lente catedrático e tomou posse da primeira cadeira do quinto ano, em 31 do mesmo mês.

Recebeu o título de conselheiro em 4 de dezembro de 1861 e a comenda de Nosso Senhor Jesus Cristo, por decreto de 21 de maio de 1874.

Foi jubilado por decreto de 25 de agosto de 1883 e, por decreto de 25 de abril de 1891, nomeado diretor da Faculdade, cargo que exerceu até 15 de agosto de 1902, dia em que faleceu o Barão de Ramalho, com 93 anos de idade, depois de uma das mais gloriosas existências consagradas ao estudo, ao ensino e à prática do direito.

\section{Obras Publicadas}

Elementos de processo criminal, para uso das Faculdades de Direito do Imperio.

São Paulo : Typographia Dois de Dezembro, de Antonio Louzada Antunes, 1856. 
Pratica civil e commercial. São Paulo : Typographia Imparcial, de Joaquim Roberto de Azevedo Marques. Obra depois refundida em a

Praxe brasileira. São Paulo : Ipiranga, 1869. $2^{\mathrm{a}}$ ed. em 1904, annotada pelo Dr. Pamphilo d'Assumpção. Duprat \& Cia., 1904.

Posttilas de pratica (Coleção completa das lições de Pratica do anno de 1865, precedidas de cinco lições de Hermeneutica Juridica e seguidas de dez de Processo Criminal, inteiramente correctas). $2^{\mathrm{a}}$ ed. São Paulo : Americana, 1872.

Instituições Orphanologicas (com uma carta do conselheiro João Chrispiniano 